\title{
CHAMOIS LEATHER TANNING ACCELERATED BY OXIDIZING AGENT OF HYDROGEN PEROXIDE
}

\author{
Ono Suparno*, E. Gumbira Sa'id, Ika A. Kartika, Muslich, Shiva Amwaliya \\ Department of Agroindustrial Technology \\ Faculty of Agricultural Engineering and Technology \\ Bogor Agricultural University (IPB) \\ Darmaga Campus, PO Box 220, Bogor 16002 \\ Email: ono.suparno@ipb.ac.id
}

\begin{abstract}
A weakness of chamois leather production practiced nowadays is its oxidation process taking relatively long time, i.e. nine days to two weeks. The use of an oxidizing agent was reported to shorten the oxidation process of the tanning. Appropriate condition for the tanning needs to be applied in order to improve the process efficiency and to obtain satisfactory quality leather. In this study, the best oxidation times inside and outside the rotary drum of the tanning accelerated by hydrogen peroxide were investigated. The experiment was conducted by tanning of pickled goatskin for 4, 6, and 8 hours oxidation times inside the rotary drum and 1,2, and 3 days of oxidation times outside the drum. The physical and organoleptic properties of the leathers were tested. The physical and organoleptic properties of the leathers resulted by this study met the quality requirements for the chamois leather. The best conditions for the tanning were oxidation times of eight hours inside the rotary drum and one day outside the rotary drum.
\end{abstract}

Keywords: acceleration, chamois leather, hydrogen peroxide, oxidation time, rubber seed oil, tanning

\begin{abstract}
Abstrak
Kelemahan dari produksi kulit samoa yang dipraktekkan saat ini adalah proses oksidasinya yang memerlukan waktu yang relatif lama, yaitu sembilan hari sampai dua minggu. Penggunaan bahan pengoksidasi dilaporkan dapat mempersingkat proses oksidasi pada penyamakan tersebut. Kondisi yang sesuai untuk penyamakan tersebut diperlukan untuk meningkatkan efisiensi proses dan untuk mendapatkan kulit samak bermutu tinggi. Dalam studi ini, diteliti waktu oksidasi terbaik di dalam dan di luar drum berputar pada penyamakan kulit samoa yang dipercepat menggunakan hidrogen peroksida. Penelitian dilakukan dengan menyamak kulit pikel kambing selama 4, 6, dan 8 jam waktu oksidasi di dalam drum berputar dan 1, 2, dan 3 hari waktu oksidasi di luar drum. Sifat-sifat fisik dan organoleptik dari kulit samak diuji. Sifat-sifat fisik dan organoleptik dari kulit samoa yang dihasilkan dari peneltian ini memenuhi persyaratan mutu kulit samoa. Waktu oksidasi terbaik adalah delapan jam oksidasi di dalam drum berputar dan satu hari oksidasi di luar drum berputar.
\end{abstract}

Kata kunci: percepatan, kulit samoa, hidrogen peroksida, waktu oksidasi, minyak biji karet, penyamakan

*corresponding author 


\section{Introduction}

Leather products have many applications and high economic value. This is due to tanning converts raw skin or hide into leather which is durable and stable against physical, biological, and chemical influences, so it can be used for variety of applications and products (Suparno et al., 2005).

One of leather final products is oil tanned leather or known as chamois leather. In traditional practice, production of the chamois leather is by impregnating wet pickled sheepskin with fish oil in the fulling stocks and then hanging it in warm stoves for the oil oxidation (Sharphouse, 1985).

Chamois leather is a popular leather article in the market, as it has many uses and aesthetic value. The demand for the chamois leather in the global market increases continuously (Krishnan et al., 2005). Use of the chamois leather is widespread and diverse. The leather has a unique use in filtration of high-grade gasoline, cleaning and drying of optical instruments, manufacturing of gloves, garments, and orthopaedic leather.

Oil tanning practiced nowadays has some weaknesses, such as requiring a long oxidation time, i.e. nine days to two weeks (Hongru et al., 2008; Suparno, 2010). This causes overall production time to become relatively long; thereby it reduces the efficiency of the process and directly affects the production capacity of the leather industry.

Our previous study has shown that the addition of hydrogen peroxide $\left(\mathrm{H}_{2} \mathrm{O}_{2}\right)$ was able to accelerate the oxidation time of the production of chamois leather (Suparno et al., 2011). However, currently the appropriate oxidation time for chamois leather using rubber seed oil and hydrogen peroxide has not been known. Appropriate oxidation time in the tanning is necessary to improve efficiency of the process and quality of the leather, thus it will increase added value of the product. The objectives of this study were to investigate the effect of oxidation time in the chamois tanning on the chamois leather quality and to determine the best condition of oxidation time for the tanning accelerated by hydrogen peroxide.

\section{Methodology}

\subsection{Materials and equipment}

The materials used in this study were pickled goatskin, rubber seed oil, hydrogen peroxide, glutaraldehyde (Relugan GT50), degreaser, formic acid, sodium carbonate, and salt. The equipment used in the tanning were rotary drum, stacking, buffing machine, shaving machine, sammying machine, toggle dryer, and the horses. Physical testing equipment used were thickness gauge, Kubelka glass apparatus, tensile strength tester (UTM Instron), caliper, and scissors.

\subsection{Tanning}

Tanning process consisted of $\mathrm{pH}$ adjustment, pretanning, fixation, aging, shaving, washing, oil tanning, washing, toggling, drying, and buffing. The oil tanning was carried out by using a modified method of Suparno et al. (2009). The modifications were the additions of oil diffusion process conducted in the rotary drum for 8 hours and oxidation processes inside the drum for 4,6 , and 8 hours. The inside rotary drum oxidation process was undertaken by using hydrogen peroxide as oxidation agent with concentrations of $6 \%$ based on the weight of rubber seed oil used. The outside rotary drum (hung on the toggle dryer) oxidation process was carried out for 1,2 , and 3 days. The tanning procedure is shown in Table 1.

\subsection{Leather testing}

Physical and organoleptic properties of chamois leathers were tested. Physical properties, which were water absorption, tear strength, tensile strength, and elongation at break, were measured using SLTC methods (Society of Leather Technologists and Chemists, 1996). Organoleptic properties, i.e. softness, colour and odour, were tested by two chamois leather experts.

\section{Results and Discussion 3.1 Water absorption}

Water absorption is the leather ability to absorb water per weight unit of leather and expressed in percentage. Water absorption is an important parameter in determining the quality of chamois leather, as the main use of the leather is as a filtering, cleaning and drying agents that require high water absorption capacity. The higher water absorption of the chamois leather, the better its quality.

Measurement of water absorption was carried out for the first 2 hours of water absorption by the leather samples. This study shows that water absorptions are in the range of 291.4- 
$357.6 \%$ (Figure 1). In general, the water absorption of the chamois leathers in this study met the standard of SNI 06-1752-1990 (BSN, 1990), i.e. minimum of $100 \%$.

Water absorption was affected significantly by oxidation time inside the rotary drum, while oxidation time outside rotary drum and the interaction between those two factors did not significantly affect the value of water absorption. The highest water absorption was obtained in the treatment with inside rotary drum oxidation time of 4 hours (Figure 1).

Table 1. Procedure of tanning using rubber seed oil (modification from Suparno et al., 2009)

\begin{tabular}{|c|c|c|c|c|}
\hline Process & Chemical & Amount & Duration & Remark \\
\hline \multirow[t]{3}{*}{ pH adjustment } & Water & $200 \%$ & & Drum at $8 \mathrm{rpm}$ \\
\hline & $\mathrm{NaCl}$ & $10 \%$ & 10 mins & Measure $\mathrm{pH}$ at 3 and ${ }^{\circ} \mathrm{Be}$ at 8 \\
\hline & Formic acid & & & \\
\hline Pretanning & Relugan GT50 & $1.5 \%$ & $\begin{array}{l}4 \times 15 \text { mins, } \\
\text { then } 1 \mathrm{~h}\end{array}$ & $\begin{array}{l}\text { Dilute with water } 3 \text { times } \\
\text { Drum at } 12 \mathrm{rpm}\end{array}$ \\
\hline \multirow[t]{2}{*}{ Fixation } & Sodium formic & $1 \%$ & $4 \times 10$ mins & Dilute 20 times \\
\hline & $\begin{array}{l}\text { Sodium carbonate } \\
\text { Drain }\end{array}$ & $1 \%$ & $\begin{array}{l}- \\
-\end{array}$ & Measure $\mathrm{pH}$ at 8 \\
\hline Aging & - & - & Overnight & Cover with plastic \\
\hline Shaving & & & & Shave both sides \\
\hline Washing & $\begin{array}{l}\text { Water } \\
\text { Drain }\end{array}$ & $1000 \%$ & $3 \times 15$ mins. & \\
\hline \multirow[t]{5}{*}{ Oil tanning } & Water & $200 \%$ & 10 mins & Drum at $8 \mathrm{rpm}$ \\
\hline & Sodium carbonate & $0.5 \%$ & & \\
\hline & Rubber seed oil & $30 \%$ & & $\begin{array}{l}\text { Leave overnight } \\
\text { Drum for } 8 \mathrm{~h}\end{array}$ \\
\hline & $\begin{array}{l}\text { Oxidation inside } \\
\text { the rotary drum }\end{array}$ & & $\begin{array}{l}4,6 \text {, and } 8 \\
\text { hours }\end{array}$ & Rotate in the drum \\
\hline & $\begin{array}{l}\text { Oxidation outside } \\
\text { the drum }\end{array}$ & & $\begin{array}{l}1,2 \text {, and } 3 \\
\text { days }\end{array}$ & $\begin{array}{l}\text { Hang on the tiggle drier at } \\
\text { room temperature }\end{array}$ \\
\hline \multirow[t]{4}{*}{ Washing } & Sodium carbonate & $3 \%$ & & Stake \\
\hline & Degreaser & $0.2 \%$ & & Repeat 3 times \\
\hline & Water & $300 \%$ & & \\
\hline & Drain & & & \\
\hline $\begin{array}{l}\text { Toggling and } \\
\text { drying }\end{array}$ & - & - & 1 day & - \\
\hline Buffing & - & - & - & Buff both sides \\
\hline
\end{tabular}

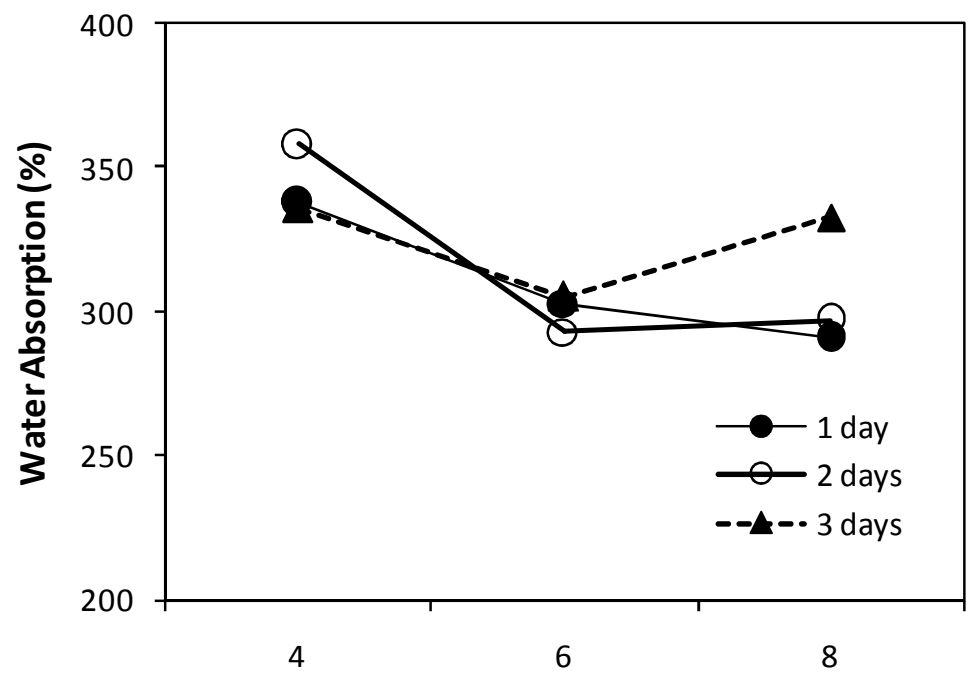

Oxidation Time Inside the Rotary Drum (hour)

Figure 1. The relationship between oxidation times inside and outside the rotary drum and the water absorption of chamois leather 
The treatment of 4 hours inside the rotary drum oxidation time gave a significantly different effect compared to the oxidation time of 6 hours and 8 hours, whereas the treatment of 6 hours and 8 hours gave almost the same or not significant effect. Oxidation time of 4 hours gave the highest average value of water absorption, $344 \%$. This could be due to longer oxidation time in the drum can lead to more dominant oxidative reaction on the leather surface, so that when the leather is oxidized in the open air outside the drum, oxygen from the air can not oxidize the oil in the deeper layer of the leather, because it was blocked by the oxidation products on the leather surface.

\subsection{Tear Strength}

Tear strengths of chamois leathers resulted in this study were in the range of 58.4-70.8 N/mm (Figure 2). In general, the tear strength of the leathers fulfilled the SNI 06-1752-1990 (Badan Standarisasi Nasional, 1990), where the tear strength must be at least $15 \mathrm{~N} / \mathrm{mm}$.

\subsection{Tensile Strength}

Tensile strengths of chamois leathers resulted in this experiment were in the range of 25.0-32.7 $\mathrm{N} / \mathrm{mm}^{2}$ (Figure 3). In general, the tensile strengths met the standard of SNI 061752-1990 (Badan Standarisasi Nasional, 1990), i.e. minimum of $7.5 \mathrm{~N} / \mathrm{mm}^{2}$.

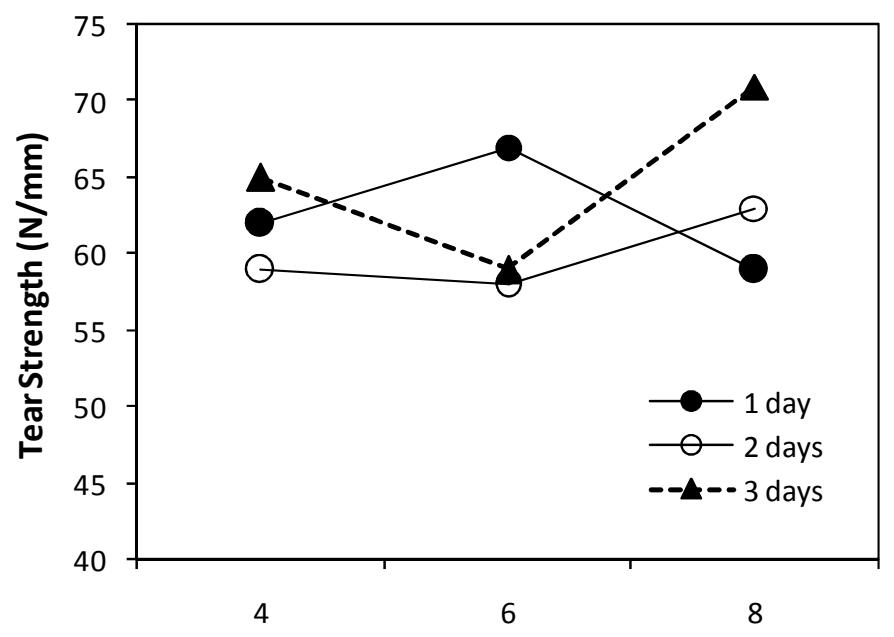

Oxidation Time Inside the Rotary Drum (hour)

Figure 2. The relationship between oxidation times inside and outside the drum and the tear strength of chamois leather

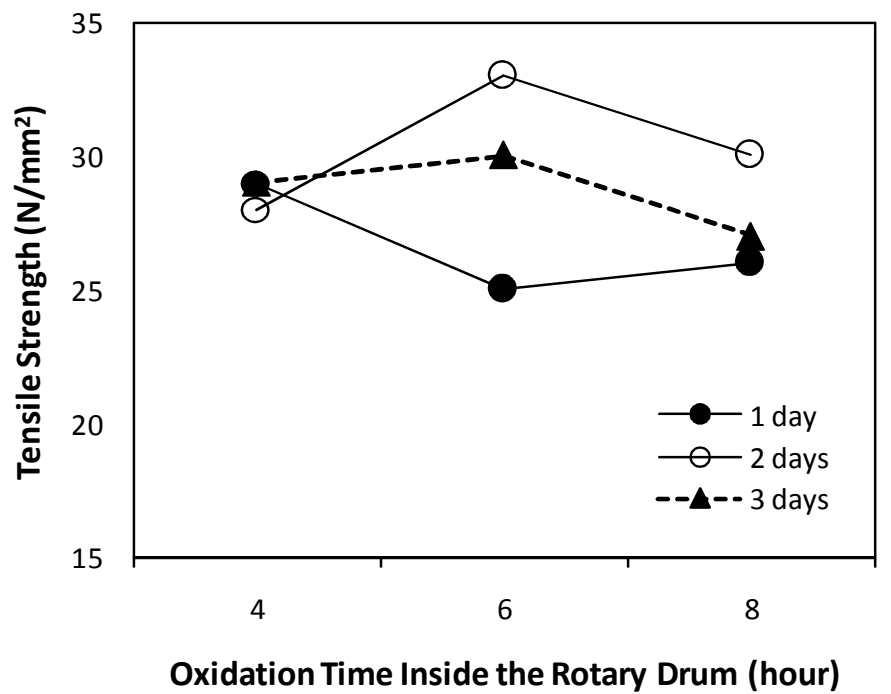

Figure 3. The relationship between oxidation times inside and outside the drum and the tensile strength of chamois leather 
Oxidation time outside the drum gave a significantly different effect on the value of tensile strength, while oxidation time inside the the drum and the interaction between those two factors did not give significantly effect. The presence of oxygen in the air when the leather is oxidized outside the drum can help the process of oxidation. Oxidation by oxygen from the air occurs spontaneously if material containing oil or fat is left in contact with air (Ketaren, 2008). In addition, when oxidation at outside the drum, the leather was stretched on a toggle dryer, so there was dry air flowing on both sides of the leather causing a stiffer, drier, and stronger leather.

The oxidation time outside the drum for 3 days did not gave significantly different effect compared to the treatment of 1 day and 2 days, but treatment of 1 day outside the drum gave a significantly different effect compared to the 2 day treatment. Treatment of 2 days outside the drum gave the highest average value, $30.2 \mathrm{~N} / \mathrm{mm}^{2}$.

\subsection{Elongation at break}

Elongation at breaks of chamois leathers resulted in this study were in the range of $138.3-175.7 \%$ (Figure 4). Generally, elongation at breaks of the leathers met the standard of SNI 06-1752-1990 (BSN, 1990), i.e. minimum of $50 \%$.

Oxidation times inside and outside the drum, as well as the interaction between those two factors did not give significantly different effect on the average values of elongation at breaks. This means that the treatments used in this study gave similar effects on the elongation at break of the leathers.

\subsection{Organoleptic properties}

Organoleptic properties are important parameter for determining the quality of chamois leather. The organoleptic properties of the chamois leather are softness, colour, and odour (BSN, 1990).

\subsection{Softness}

Softness of chamois leather is very important to prevent the items cleaned or dried scratched, as the chamois leather is usually used for cleaning or drying. Besides, soft leather tends to increase its water absorption and flexibility, so it will provide comfort during use.

Based on Figure 5, it can be seen that softness of the leathers obtained from this study were in the range of 4 to 9 . This means that the softness of the leathers were good to very good.

Oxidation time inside the drum gave a significantly different effect on the leather softness, whereas oxidation time outside the drum and the interaction between those two factors did not gave significantly different effect. This is due to the addition of $\mathrm{H}_{2} \mathrm{O}_{2}$ as oxidizing agent was inside the drum, so its ability to oxidize the oil in the drum was more optimum than that of when the leather was

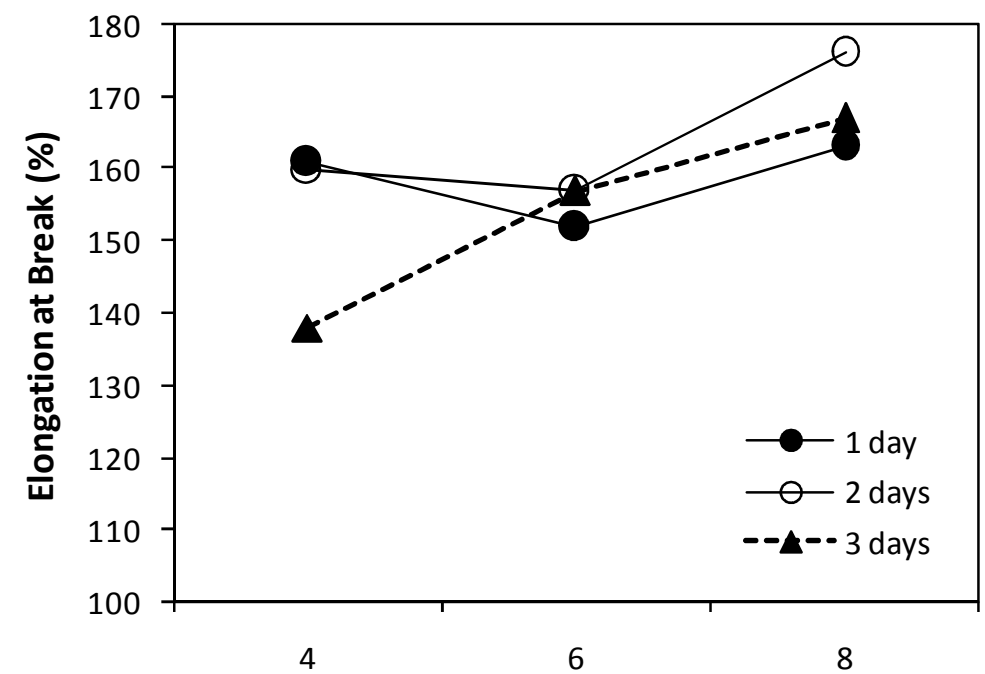

Oxidation Time Inside the Rotary Drum (hour)

Figure 4. The relationship between oxidation times inside and outside the drum and the elongation at break 


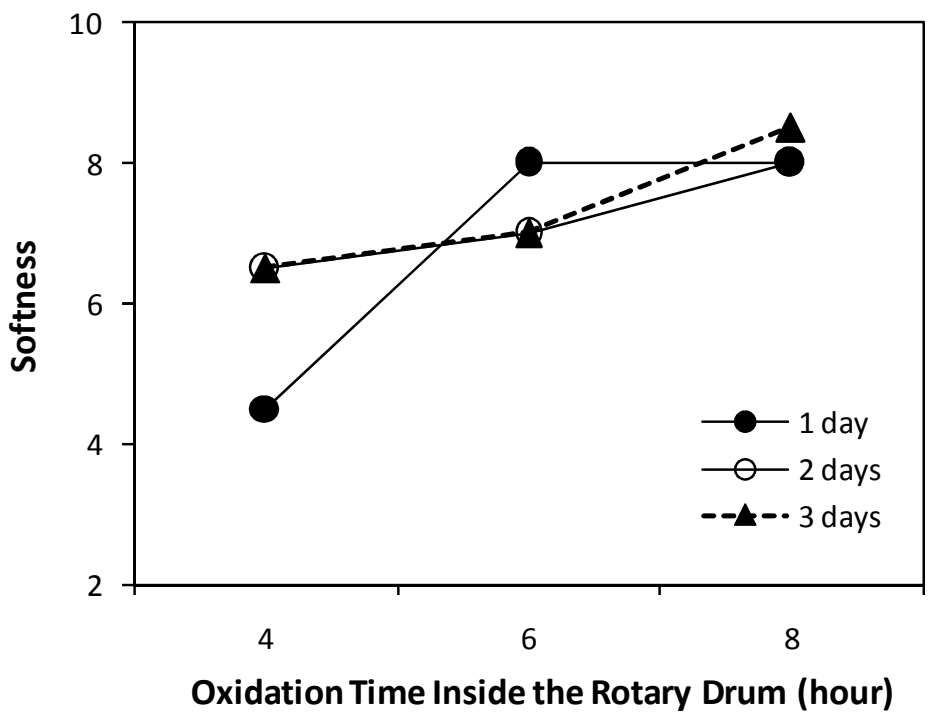

Figure 5. The relationship between oxidation times inside and outside the drum and the softness of chamois leather

left in the open air outside the drum. The highest value (8-9) of the softness was given by combination of inside drum oxidation time treatment of 8 hours and outside the drum of 3 days.

The inside the drum oxidation time of 6 hours was not significantly different from that of 8 hours, but they were different significantly with oxidation time of 4 hours. The treatment of 4 hours of oxidation time inside the drum produced the lowest value of softness with the average value of 5.8 . Oxidation time of 8 hours inside the drum gave the highst average value of softness, i.e. 8.2 .

\subsection{Colour}

Colour of chamois leather indicates the level of brightness and cleanliness of the leather. According to the SNI 06-1752-1990, preferred colour of chamois leather is yellow to nearly white (BSN, 1990).

Organoleptic test on colour provided the results that leather colour values were in the range of 7-8 (Figure 6). The leathers were pale yellow. The yellow colour was mainly due to the oxidation of linoleic glycerides forming a yellow unsaturated ketone compound. The yellow colour can also be produced from protein and nitrogen bases extracted together with oxidized oil (Ketaren, 2008).

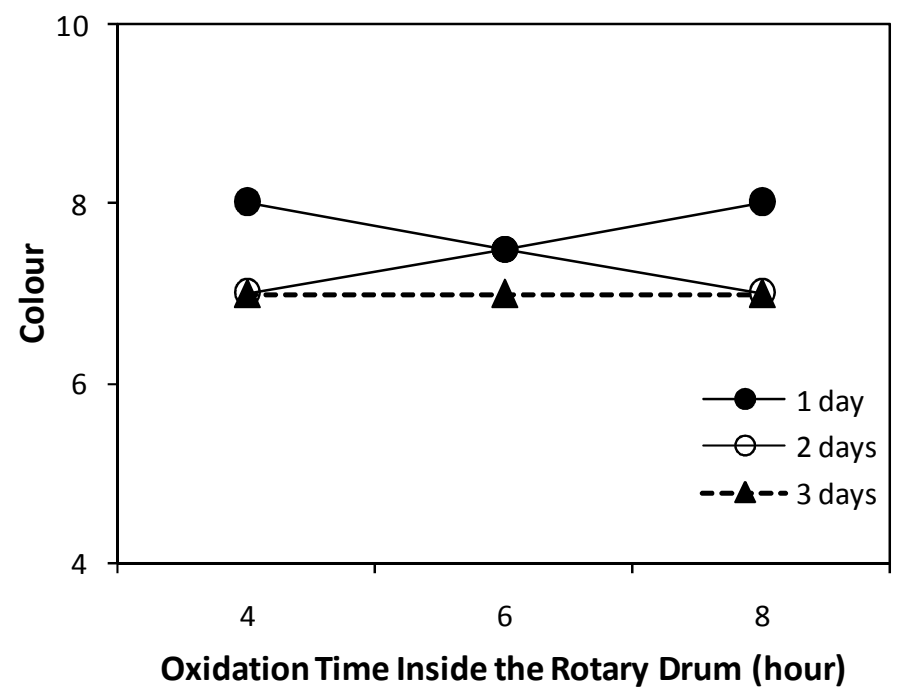

Figure 6. The relationship between the inside and outside oxidation times and the colour of chamois leather 
Oxidation time outside the drum gave a significantly different effect on the value of colour, whereas oxidation time inside the drum and the interaction between those two factors did not give significant effect. This was due to when the leather was oxidized outside the drum, the leather was stretched and both sides were in contact with the outside air resulting in further oxidation and increasing colour intensity.

The outside of the drum oxidation time of 1 day gave a significantly different effect compared to the oxidation times of 2 and 3 days, while the outside the drum oxidation time of 2 days was not significantly different from 3 days. Outside the drum oxidation time of 1 day provided the highest colour values, with the average value of 7.8. Oxidation time of 3 days gave the lowest average colour value of 7. This is due to the longer the ouside the drum oxidation time, it will be the longer the leather contacts with the air and more oil is oxidized, so that the resulting colour intensity increased to brownish yellow. High colour intensity is not desirable for chamois leather, as according to BSN (1990), the preferred colour of chamois leather is yellow to nearly white.

\subsection{Odour}

Odour contained in the chamois leather is generally caused by oil residue left on the leather due to an insufficient washing process. Undesirable odour will decrease the aesthetic and consumer appeal on the product.
From the odour test, all combinations of treatments provided the same odour value, i.e. 7-8 (Figure 7). This suggests that the combinations of oxidation times tried in the tanning did not give significantly different effect on the odour of leather. Generally, odour of chamois leather is dependent upon washing process of the leather after oil oxidation. Insufficient washing process can leave an undesirable odour, since the odour is generated by the oil residue sticking to the leather, if it is not completely washed away.

\section{Conclusion}

Combination of oxidation times inside and outside the drum in the chamois tanning process gave influence on the quality of chamois leather. Oxidation time inside the drum affected water absorption and softness of the leather. Oxidation time outside the drum gave effect on tear strength, tensile strength, and colour of the leather.

The combination of oxidation times inside the drum of eight hours and outside the drum of one day was a selected treatment to produce the chamois leather. The treatment produced chamois leather with high water absorption and organoleptic properties.

Tanning with the selected treatment resulted in chamois leather with properties as follows: water absorption of 291.4\%, tear strength of $59.5 \mathrm{~N} / \mathrm{mm}$, tensile strength of $26.2 \mathrm{~N} / \mathrm{mm}^{2}$, elongation at break of $163.3 \%$, softness and colour of 8 , and odour of 7.5.

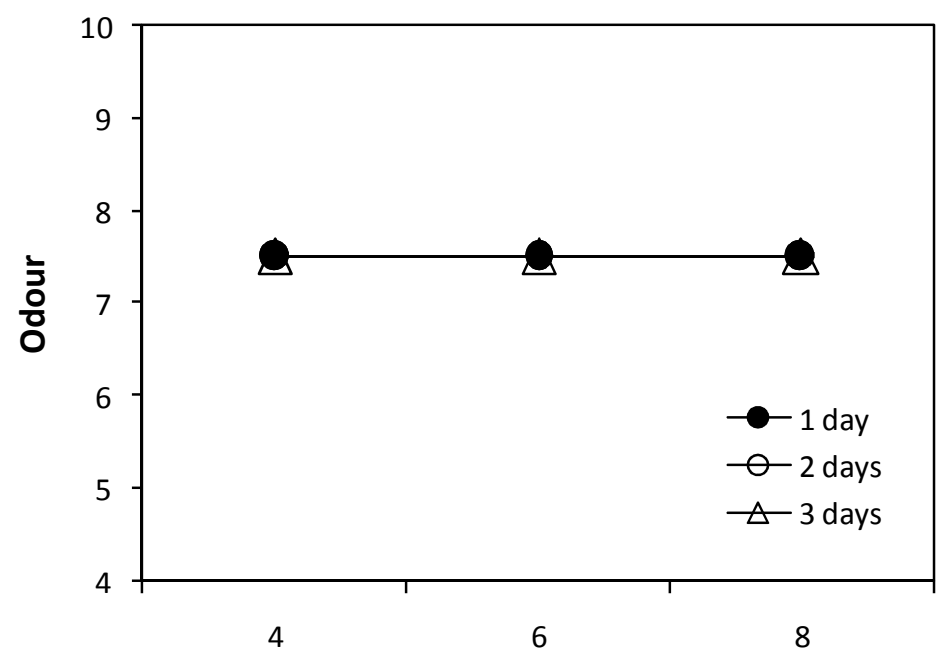

Oxidation Time Inside the Rotary Drum (hour)

Figure 7. The relationship between the inside and outside the drum oxidation times and the odour of chamois leather 


\section{References}

Badan Standarisasi Nasional, Indonesia National Standard for Chamois Leather - SNI 06-1752-1990; Jakarta, 1990.

Hongru, W.; Yuanyue, M.; Yue, N., An oil tanning process accelerated by oxidation with sodium percarbonate, Journal of the Society of Leather Technologists and Chemists, 2008, 92(5), 205-209.

Ketaren, S., Introduction to Technology of Food, Oil and Fat, UI-Press: Jakarta, 2008.

Krishnan, S. H.; Sundar, V. J.; Rangasamy, T.; Muralidharan, C.; Sadulla, S., Studies on chamois leather tanning using plant oil Journal of the Society of Leather Technologists and Chemists, 2005, 89(6), 260-262.

Sharphouse, J. H., Theory and practice of modern chamois leather production, Journal of the Society of Leather Technologists and Chemists, 1985, 69(2), 29-43.

Society of Leather Technologists and Chemists, Official Methods of Analysis; Northampton, 1996.
Suparno, 0., Optimization of chamois leather tanning using rubber seed oil, Journal of the American Leather Chemists' Association, 2010, 105(6), 189-194.

Suparno, O.; Covington, A. D.; Evans, C. S., Kraft lignin degradation products for tanning and dyeing of leather, Journal of Chemical Technology and Biotechnology, 2005, 80(1), 44-49.

Suparno, O.; Gumbira-Sa'id, E.; Kartika, I. A.; Muslich; Mubarak, S., An innovative new application of oxidizing agents to accelerate chamois leather tanning. Part I: The effects of oxidizing agents on chamois leather quality, Journal of the American Leather Chemists' Association, 2011, 106, 360-366.

Suparno, 0.; Kartika, I. A.; Muslich, Chamois leather tanning using rubber seed oil, Journal of the Society of Leather Technologists and Chemists, 2009, 93(4), 158-161. 